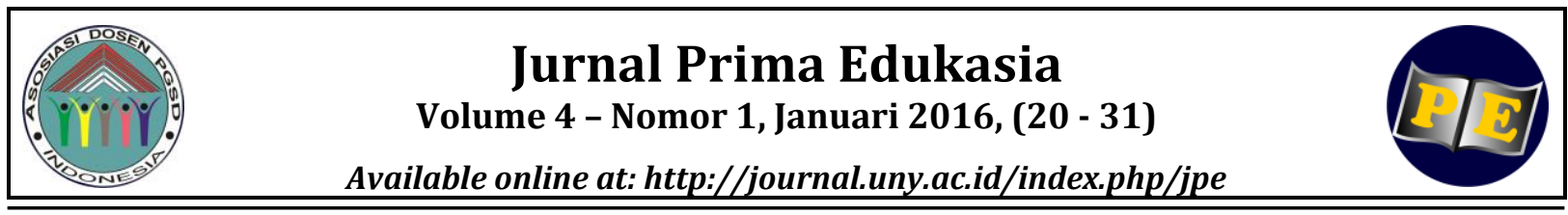

\title{
IMPLEMENTASI PENDEKATAN SAINTIFIK DALAM PEMBELAJARAN IPS DI MIDDLE GRADE SD TUMBUH 3 KOTA YOGYAKARTA
}

\author{
Anastasia Endah Anastika Dewi ${ }^{1)}$, Mukminan ${ }^{2)}$ \\ ${ }^{1}$ Program Studi Pendidikan Dasar, Program Pascasarjana, Universitas Negeri Yogyakarta. Jalan \\ Colombo No.1, Karangmalang, Yogyakarta 55281, Indonesia \\ ${ }^{2}$ Jurusan Pendidikan Geografi, Universitas Negeri Yogyakarta. Jalan Colombo No.1, Karangmalang \\ Yogyakarta 55281, Indonesia \\ Email: ${ }^{1}$ anastasiaaead@gmail.com, ${ }^{2}$ mukminan@yahoo.co.id
}

\begin{abstract}
Abstrak
Penelitian ini bertujuan untuk: (1) Mendapatkan bukti-bukti otentik implementasi pendekatan saintifik, (2) Menilai kesesuaian pendekatan saintifik. (3) Menemukan faktor-faktor penghambat dan pendukung implementasi pendekatan saintifik pada pembelajaran IPS di middle grade SD Tumbuh 3 Kota Yogyakarta. Penelitian ini merupakan penelitian kualitatif menggunakan desain studi kasus. Hasil penelitian menunjukkan: (1) Implementasi pendekatan saintifik meliputi sudah sesuai kurikulum dan, pelaksanaan sesuai tahapan pendekatan saintifik, penilaian belum sesuai penilaian otentik, tindak lanjut sudah sesuai. (2) Penerapan pendekatan saintifik pada pembelajaran IPS untuk siswa middle grade sesuai dengan perkembangan berfikir dan proses belajar siswa. (3) Faktor pendukung pendekatan saintifik adalah: kepala sekolah, guru yang profesional, iklim sekolah yang kondusif, sarana dan prasarana yang lengkap. Faktor penghambatnya adalah: sistem penerimaan siswa tidak transparan, ada beberapa peserta didik belum bisa membaca dan menulis, instrumen penilaian tidak sesuai, dan jam pembelajaran yang terbatas dan guru tidak membatasi bobot cakupan materi sesuai dengan tingkat perkembangan berpikir siswa.
\end{abstract}

Kata kunci: implementasi, pendekatan saintifik, middle grade, IPS

\section{IMPLEMENTATION OF SCIENTIFIC APPROACH IN SOCIAL STUDIES INSTRUCTION AT MIDDLE GRADE OF SD TUMBUH 3 KOTA YOGYAKARTA}

\begin{abstract}
This study aims to: (1) Getting authentic proof of scientific approach implementation (2) Asses the scientific approach appropriateness in social studies, (3) to find some factors that become the barriers and the proponents of the scientific approach implementation in social studies instruction in middle grade. This study is a qualitative research which uses case study design. The results of this reasearch are as follows: (1) The scientific approach implementation ranges from, the planning aspect has already been appropriate, the implementation aspect has already been good, the assessment aspect has not been appropriate to the approach used, the follow-up aspect has been carried out based on the students' need. (2) Scientific approach in for middle-grade age has already been appropriate,(3) The supporting factors are: a good headmaster, professional teache, The conductive school climate, the complete facilities and infrastructures. The inhibiting factors are: the nontransparent admission system, students who have not been able to read and write, the inappropriate assessment, and limited schedule of social studies the teacher do not limit the range of Social Studies material based on student's cognitive development stage.
\end{abstract}

Keywords: implementation, scientific approach, middle grade, social studies

How to Cite: Dewi, A., \& Mukminan, M. (2016). Implementasi pendekatan saintifik dalam pembelajaran IPS di middle grade SD Tumbuh 3 Yogyakarta. Jurnal Prima Edukasia, 4(1), 20 - 31. Retrieved fromhttp://journal.uny.ac.id/index.php/jpe/article/view/7691 
Jurnal Prima Edukasia, 4 (1), Januari 2016 - 21

Anastasia Endah Anastika Dewi, Mukminan

\section{Pendahuluan}

Undang-Undang No. 20 Tahun 2003, Pasal 1 butir I tentang Sistem Pendidikan Nasional menyatakan bahwa pendidikan adalah usaha sadar dan terencana untuk mewujudkan suasana belajar dan proses pembelajaran agar peserta didik secara aktif mengembangkan potensi dirinya untuk memiliki kekuatan spiritual, keagamaan, pengendalian diri, kepribadian, akhlak mulia, serta keterampilan yang diperlukan dirinya, masyarakat, bangsa dan negara. Dalam Bab II pasal 3 dijelaskan bahwa pendidikan berfungsi mengembangkan kemampuan dan membentuk watak serta peradaban bangsa yang bermartabat dalam rangka mencerdaskan kehidupan bangsa, bertujuan untuk mengembangkan potensi peserta didik agar menjadi manusia yang beriman dan bertakwa kepada Tuhan Yang Maha Esa, berakhklak mulia, sehat, berilmu, cakap, kreatif, mandiri, dan menjadi warga negara yang demokratis, serta bertanggung jawab.

Bila dicermati rumusan tujuan pada UU No 20 Tahun 2003 tersebut ternyata menyangkut semua aspek kehidupan manusia baik yang menyangkut keimanannya, sikap dan kepribadiannya, kecerdasannya, keterampilannya, menyangkut aspek jasmani, rohani, dan moral keagamaan. Nilai-nilai tersebut sudah seharusnya ditanamkan sejak dini pada usia sekolah dasar, salah satunya melalui pembelajaran yang tepat. Salah satu pembelajaran yang berkaitan erat dengan kehidupan sehari-hari peserta didik adalah Ilmu Pengetahuan Sosial (IPS). Keberhasilan suatu pembelajaran tidak lepas dari pendekatan apa yang digunakan oleh guru. Dengan menggunakan pendekatan yang tepat diharapkan tujuan pembelajaran tercapai dengan baik sehingga dapat membimbing peserta didik meraih semua kemampuan yang menjadi tujuan dari pendidikan nasional.

Pembelajaran dikatakan berhasil mengantarkan peserta didik mencapai tujuan yang diharapkan dipengaruhi oleh beberapa faktor, salah satunya adalah pendekatan yang digunakan oleh guru. Pendekatan yang saat ini sedang dilakukan terkait dengan kurikulum 2013 adalah pendekatan saintifik. Pembelajaran IPS dalam pelaksanaannya mengalami hambatan dan kendala terlebih jika diajarkan melalui pendekatan saintifik. Seperti yang diungkapkan oleh Holbrook (2008, p.3) sebagai berikut.

Limitations of the Scientific Approach in the Social Sciences: (a) complexity of subject matter, (b) difficulties in observation, (c) difficulties in replication, (d) interaction of observer and subjects, (e) difficulties in control, (f) problems of measurement.

Berdasarkan hasil prasurvei sekolah di Yogyakarta yang telah menggunakan pendekatan saintifik dalam pembelajaran sejak tahun 2012 akan menjadi sumber dan wacana bagi penelitian ini. Sekolah yang dimaksud adalah SD Tumbuh 3 Kota Yogyakarta. Mengusung semangat untuk dapat menghadirkan buktibukti otentik tentang bagaimana pelaksanaan pembelajaran IPS melalui pendekatan saintifik mulai dari aspek perencanaan sampai pada tindak lanjut bagi sekolah agar dapat maksimal mengimplementasikan pendekatan saintifik dalam pembelajaran IPS. Fokus penelitian dilaksanakan di kelas middle atau kelas dengan kelompok usia menengah dari 8-9 tahun. Pemilihan kelas disesuiakan dengan karakter dan kemampuan belajar siswa yang sudah lebih mampu menerima pembelajaran dengan tahapan yang sistematis mulai dari hal konkret sampai kepada konsep yang lebih kompleks.

Tujuan penelitian ini adalah untuk mendeskripsikan dan memaknai implementasi pendekatan saintifik dalam pembelajaran IPS di middle grade SD Tumbuh 3 Kota Yogyakarta. Manfaat penelitian ini secara teoritis memberikan sumbangan pemikiran ilmiah untuk perkembangan pendidikan pada sekolah dasar di Kota Yogyakarta dalam menerapkan pendekatan saintifik dalam pembelajaran IPS. Manfaat penelitian ini secara praktis sebagai dorongan untuk mendesain pembelajaran IPS dengan pendekatan saintifik yang kreatif dan inovatif sehingga mampu meningkatkan hasil belajar peserta didik.

\section{Metode}

Penelitian ini bertujuan untuk mendeskripsikan proses dan implementasi pendekatan saintifik pada pembelajaran IPS di SD Tumbuh 3 Kota Yogyakarta. jenis penelitian yang digunakan adalah kualitatif dengan desain studi kasus.

\section{Tempat dan Waktu Penelitian}

Penelitian dilaksanakan di SD Tumbuh 3 Kota Yogyakarta. Sekolah ini dipilih sebagai lokasi penelitian karena sekolah ini merupakan satu-satunya sekolah dasar di Yogyakarta yang telah menggunakan pendekatan saintifik dalam pembelajaran dan berlangsung sudah cukup 
Jurnal Prima Edukasia, 4 (1), Januari 2016 - 22

Anastasia Endah Anastika Dewi, Mukminan

lama semenjak awal berdirinya pada tahun 2012.

Waktu yang diperlukan untuk mengumpulkan data dan menganalisisnya berlangsung mulai dari bulan November menjelang akhir semester I sampai dengan minggu ketiga tanggal 15 Maret 2015, saat pembelajaran dalam satu tema selesai. Hal ini sesuai dengan prinsip pendekatan penelitian kualitatif, di mana data yang diperoleh harus sampai jenuh.

\section{Subjek dan Objek Penelitian}

Subjek penelitian ini adalah: (1) Kepala sekolah: kepala sekolah menjadi subjek penelitian untuk memperoleh keterangan mengenai kondisi sekolah dan gambaran pembelajaran secara umum di sekolah tersebu. (2) Wakil kepala sekolah: wakil kepala sekolah yang menjadi subjek disini adalah wakil kepala sekolah bagian kurikulum. Kurikulum sangat erat kaitannya dengan pelaksanaan pembelajaran yang di dalamnya mencakup pendekatan saintifik. (3) Guru kelas: guru yang menjadi subjek penelitian adalah guru yang telah mempunyai pengalaman mengajar lebih dari 1 tahun di sekolah tersebut. Dan merupakan lulusan Strata 1 (S-1) pendidikan sekolah dasar, khususnya guru di middle grade SD Tumbuh 3 Kota Yogyakarta. (4) Siswa: siswa yang menjadi subjek penelitian merupakan siswa yang bersekolah di SD tersebut sejak mulai lower grade (kelas rendah) sampai ke middle grade (Usia 8-9 tahun).

Objek dalam penelitian ini adalah proses pembelajaran dengan pendekatan saintifik da- lam pembelajaran IPS di kelas middle grade SD Tumbuh 3 Kota Yogyakarta.

Teknik Pengumpulan Data

Data yang dicari dalam penelitian ini adalah data kualitatif yang berupa kata-kata (ungkapan verbal) sikap, perilaku, dan aktivitas subjek penelitian yang berkaitan dengan fokus penelitian. Untuk mendapatkan data dari subjek tetang objek penelitian itu digunakan tiga teknik pengumpulan data, yaitu: observasi, wawancara, dan dokumentasi.

\section{Instrumen Penelitian}

Instrumen yang digunakan dalam penelitian ini adalah: lembar observasi, paduan wawancara mendalam, paduan analisis dokumentasi.

\section{Teknis Analisis Data}

Penelitian ini menggunakan teknik analisis data model interactive analysis Milles dan Huberman (1992, p.12). Aktivitas dalam analisis data kualitatif dilakukan secara interaktif dan berlangsung secara terus menerus sampai tuntas sehingga datanya mencapai titik jenuh.

Milles dan Huberman (1992, p.12) menetapkan empat langkah dalam menganalisis data kualitatif. Keempat langkah tersebut meliputi: pengumpulan data, reduksi data, penyajian data, dan penarikan kesimpulan atau verifikasi. Untuk memperjelas cara kerja analisis data model interaktif, dapat dilihat pada gambar berikut.

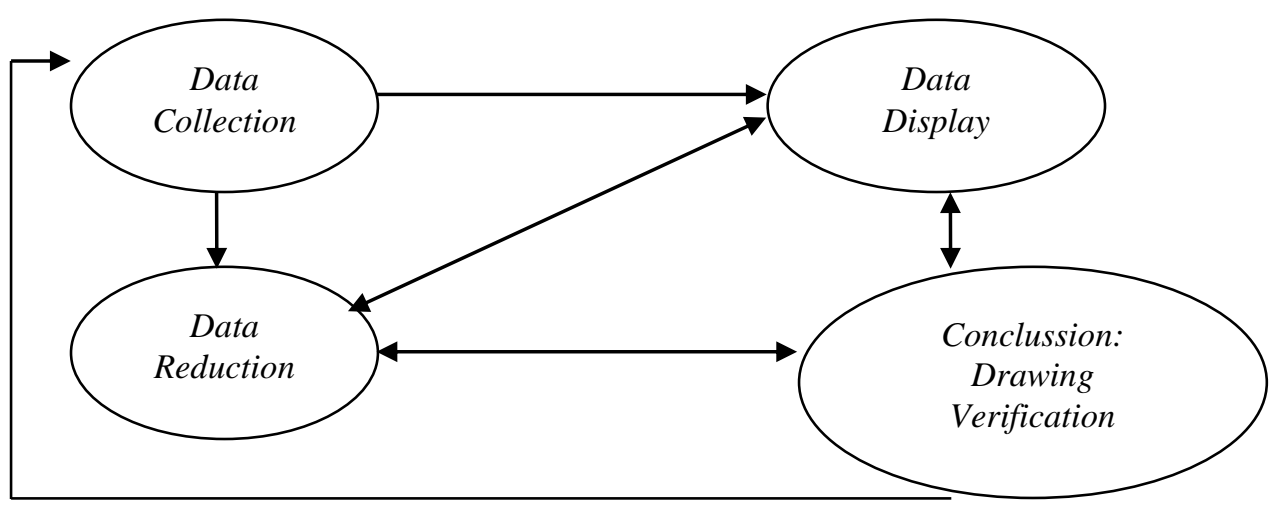

Gambar 1. Komponen Analisis Data Model Interaktif. Sumber: Milles \& Huberman, 1992, p.12.

Penelitian ini menggunakan dua cara untuk menguji keabsahan data, yaitu: triangulasi sumber dan triangulasi metode. Triangulasi sumber dengan cara mengkombinasikan lebih dari satu metode atau sumber data untuk memperoleh data yang sama. Triangulasi metode adalah memperoleh suatu data lebih dari satu sumber data dan dilacak dengan beberapa metode. 
Jurnal Prima Edukasia, 4 (1), Januari 2016 - 23

Anastasia Endah Anastika Dewi, Mukminan

\section{Hasil dan Pembahasan}

Hasil Penelitian

SD Tumbuh 3 Kota Yogyakarta terletak di J1 Dalem Mangkubumen KT III 237 Kadipaten, Kraton Yogyakarta 55132 DI Yogyakarta. Ditinjau dari letak lokasinya, sekolah ini berada di pusat Kota Yogyakarta, tepatnya di bagian kanan komplek Universitas Widya Mataram. Kekhasan daripada sekolah ini adalah telah menggunakan pendekatan saintifik sebeum disosialisasikannya Kurikulum 2013 untuk sekolah dasar pada tahun 2013. Sekolah ini berada di bawah naungan yayaysan Tumbuh dan memiliki perbedaan dari SD Tumbuh lainnya. SD Tumbuh 3 Kota Yogyakarta merupakan sekolah Tumbuh yang menggunakan Bahasa inggris sebagai bahasa komunikasi dalam pembelajarannya. Visi dan misi menjadikan pesera didik tumbuh dan berkembang sebagai pembelajar yang berkarakter, menghargai keberagaman dan kearifan lokal, mencintai tanah air dan menunjukkan kesadaran sebagai warga dunia”.

Pada peneltian ini mengambil fokus di kelas middle, atau disebut dengan middle grade, kelas dengan usia anak sekitar 8-9 tahun. Di kelas middle grade terdiri atas dua grade yaitu grade 3 atau usia anak kelas 3 berjumlah 11 orang, dan grade 4 atau usia kelas 4 dengan jumlah peserta didik 4 orang. Jumlah total siswa di middle grade adalah 15 anak.

Kondisi kelimabelas peserta didik di kelas middle grade sangat unik, mereka memiliki karakter sangat beragam. Setiap peserta didik memiliki kelebihan dan kekurangan masingmasing, baik dalam akademik, sikap dan juga hubungan sosialnya. Hal tersebut juga didukung oleh hasil wawancara dengan guru kelas middle grade sebagai berikut.

"Middle grade memang tahun ini hanya ada
satu kelas saja, namun memang kelas ini
sangat beragam dan "chalengging". Semua
karakter anak ada di kelas ini. Sesuai
dengan sekolah Tumbuh 3 yang merupakan
sekolah inklusi di kelas middle grade juga
terdapat anak yang berkebutuhan khusus,
namun sejauh ini tidak begitu menjadi
masalah. Mereka hanya need more attention
dari kita saja. Pembelajaran di kelas juga
berjalan lancar, mereka masih dapat
dikondisikan dengan baik. Selain itu karena
sekolah ini siswanya berasal dari berbagai
macam ras negara dan budaya, jadi bisa
dikatakan manner mereka tidak seperti anak-anak lain di sekolah dasar pada umumnya. Itupun juga saya alami ketika saya pertama kali bertemu dengan mereka, attention mereka dengan orang lain masih begitu kurang dan bisa dikatakan tidak begitu ramah". ( Wawancara 4. DD: Tanggal 2 Desember 2014)

Guru di middle grade terdiri atas dua guru, yaitu satu guru inti dipegang oleh Dela Destian S.Pd berusia 25 tahun, lebih sering dipanggil Ibu Dela. Ibu Dela merupakan lulusan S-1 Pendidikan Sekolah Dasar (PGSD) Universitas Negeri Yogyakarta (UNY) tahun 2012. Sedangkan guru pendamping bernama Rizal Rahman S.Pd, berusia 23 tahun, lebih sering dipanggil Bapak Rizal. Bapak Rizal merupakan lulusan Pendidikan Bahasa Inggris (PBI) Universitas Negeri Yogyakarta (UNY). Kedua guru di middle grade dapat melakukan pembagian kerja dan kerjasama dengan baik. Keduanya sebagai partner kerja yang saling melengkapi. Kedekatan diantara keduanya dapat saling melebur hangat bersama peserta didik di middle grade.

Kondisi guru di SD Tumbuh 3 Kota Yogyakarta sangat dekat dengan peserta didik, kerjasama yang terbentuk antara guru inti dan guru pendamping dapat berjalan dengan baik, pembagian tugas dapat dilakukan sesuai dengan kebutuhan yang ada. Kedekatan dengan peserta didik dapat membuat proses pembelajaran berjalan dengan lancar. kedekatan yang ada membuat peserta didik merasa nyaman dan mampu lebih percaya diri dalam mengikuti proses pembelajaran.

Hal ini juga dikuatkan oleh hasil wawancara dengan guru pendamping sebagai berikut.

"Kita memang berusaha dapat masuk ke dunia anak-anak. Apalagi kedekatan kami bertujuan untuk membuat mereka nyaman. Mengingat hampir separuh waktunya dalam sehari berada bersama kami di sekolah. Dengan harapan jika mereka merasa nyaman, dapat mendorong anak untuk lebih berani, seperti bertanya, dan diskusi dengan kita. Kedekatan yang kami bangun bukan kedekatan yang membuat anak kehilangan batasan sopan santunnya dengan guru. Hal itu tetap kami usahakan agar anak tidak berlebihan, dan paham bahwa kami tetaplah bapak dan ibu gurunya". (Wawancara 6. RR: Tanggal 5 Desember 2014) 
Jurnal Prima Edukasia, 4 (1), Januari 2016 - 24

Anastasia Endah Anastika Dewi, Mukminan

Kondisi sekolah, siswa dan guru yang ada di SD Tumbuh 3 Kota Yogyakarta memberikan gambaran lengkap hasil penelitian untuk mengungkap secara mendalam bagaimana implementasi yang akan bermuara pada pelaksanaan pembelajaran. Implementasi dalam penelitian ini adalah proses pembelajaran dengan pendekatan saintifik pada pembelajaran IPS di middle grade SD Tumbuh 3 Kota Yogyakarta.

Implementasi pembelajaran dengan pendekatan saintifik dalam pembelajaran IPS dimulai dari aspek perencanaannya, yaitu dimulai dari kurikulum. Kurikulum yang digunakan di SD Tumbuh 3 Kota Yogyakarta ada 3 macam, yaitu: International Primary Curriculum (IPC), Kurikulum 2013, dan Kurikulum Internasional Singapore. Kurikulum pertama yaitu IPC, kurikulum ini disajikan dalam satu mata pelajaran, dengan jadwal lima kali pertemuan dalam satu minggu.

IPC dalam silabusnya memiliki desain yang cukup memfasilitasi pembelajaran dengan pendekatan saintifik. Dalam setiap tema beralokasi waktu tiga bulan. Selama tiga bulan tahapan pembelajaran dari awal sampai akhir didesain sesuai dengan tahapan dalam pendekatan saintifik. Setiap awal tema pembelajaran dimulai dengan entry point, pada tahapan tersebut guru mengemas pembelajaran semenarik mungkin. Pertama, Entry point berfungsi sebagai apersepsi umum, pandangan umum tentang apa saja yang akan di pelajari dalam satu tema ke depannya. Kegiatan didalamnya bertujuan untuk menimbulkan minat peserta didik. Kedua, knowledge harvest pada tahapan ini peserta didik mulai masuk ke dalam rangkaian materi yang akan dipelajari dalam satu tema. Di akhir pengenalan materi guru akan memberikan beberapa soal yang sifatnya adalah sebagai pretest untuk mengetahui sejauh mana pemahaman peserta didik sebelum masuk ke materi yang lebih mendalam. Ketiga, the big picture, tahapan di mana peserta didik diberikan pengalaman langsung terkait pembelajaran dalam satu tema. Tahapan ini melibatkan tahapan pendekatan saintifik yang ketiga yaitu mencoba. Peserta didik menemukan contoh dan gambaran langsung dari tema yang akan dipelajari.

Tahapan selanjutnya explaning the theme, pada tahapan ini peserta didik masuk ke dalam materi terkait dengan beberapa kompetensi seperti IPS, IPA, seni, teknologi, dan pengetahuan internasional dan semuanya sesuai dengan tema yang sedang dipelajari. Pada tahapan akhir setiap tema yang menjadi keistimewaan dalam IPC untuk memfasilitasi kemampuan peserta didik dalam melakukan tahapan mengkomunikasikan adalah Student Lead Converence (SLC). Kegiatan mengkomunikasikan semua kegiatan belajar yang telah dilakukan dalam satu tema.

Kurikulum IPC yang digunakan oleh sekolah ini sudah sesuai dalam mendukung pembelajaran melalui pendekatan saintifik. Williams (2011, p.7) yang mengungkapkan bahwa "A scientific method, however, is not just how to reason or use logic to come to answers or explanations". Pendekatan saintifik bukan hanya sekedar menggunakan logika untuk mendapatkan alasan dalam menjawab dan menjelaskan, namun didalamnya terdapat proses. Tahapan yang ada di dalam IPC merupakan tahapan yang memfasilitasi untuk mendorong peserta didik agar berproses secara sistematis mulai dari mengamati sampai dengan mengkomunikasikan.

Kurikulum kedua yaitu kurikulum 2013 dengan megusung nama stand alone subject untuk mata pelajaran yang termasuk di dalamnya. Stand alone subject di SD Tumbuh 3 Kota Yogyakarta menggunakan Kurikulum 2013 meliputi mata pelajaran Bahasa Indonesia dan PKn. Pendekatan yang digunakan pada Kurikulum 2013 adalah pendekatan saintifik mulai dari mengamati, menanya, mencoba, menalar dan mengkomunikasikan.

Kurikulum ketiga yang digunakan adalah Kurikulum International dari Singapore, dengan mengusung mata pelajaran Matematika menggunakan acuan buku "My Pals". Alasan pemilihan ketiga kurikulum di SD Tumbuh 3 Kota Yogyakarta tidak lepas dari sejarah berdirinya sekolah ini, di mana sekolah ingin membentuk peserta didik menjadi pembelajar sejati melalui pengalaman belajar langsung. Pemilihan kurikulum yang dianggap sesuai untuk sekolah ini adalah IPC. Hal tersebut dikarenakan sekolah ini adalah sekolah nasional, maka kurikulum 2013 juga digunakan untuk mengajarkan beberapa mata pelajaran. Pernyataan tersebut didukung dengan hasil wawancara bersama kepala sekolah SD Tumbuh 3 Kota Yogyakarta sebagai berikut.

"Mengapa kita menggunkan IPC, dan Kurikulum 2013. Pertama untuk IPC karena kita melihat pendidikan di Finlandia yang berhasil dengan konsep fun learning nya, sekolah ini merasa memiliki teman untuk mengembangkan pembelajaran yang menggembira- 
Jurnal Prima Edukasia, 4 (1), Januari 2016 - 25

Anastasia Endah Anastika Dewi, Mukminan

kan, dan menjadikan anak sebagai pembelajar sejati melalui kurikulum yang sesuai. Dan kita melihat bahwa kurikulum yang sesuai dan cukup dapat kita pelajari dan dikembangkan disini adalah IPC. IPC lebih simpel dan recording activity-nya baik. Perlu juga kita tekankan disini, bahwa kami adalah sekolah nasional plus, bukan internasional school, sehingga kita masih menggunakan Kurikulum 2013 sesuai dengan pemerintah dan menggunakannya sebagai acuan pembelajaran untuk Bahasa Indonesia dan Pkn. Selanjutnya kurikulum Internasional Singapore kami gunakan dalam pembelajaran Matematika dengan menggunakan paduan buku My Pals."'(Wawancara 7. SRW: Tanggal 2 Desember 2014).

Penggunaan tiga kurikukulum di sekolah ini menjadi hal yang perlu diperhatikan. National Research Council (Eidities \& Jewkes, 2011, p.5) menjelaskan bahwa "a curriculum is the way content is organized and present, but the content of the curriculum can be organized and presented with many different emphases and perspectives". Kurikulum dapat berkembang sesuai dengan situasi dan kondisi selama masih berpegang pada pedoman/standar yang telah ditetapkan. Penggunaan tiga kurikulum jika dalam perkembangannnya nanti masih sesuai dengan standar yang ditetapkan tidak akan menjadi kendala yang berarti, namun jika perkembangan yang terjadi tidak seimbang dapat berakibat peserta didik mengalami kebingungan dengan masing-masing karakter dari semua kurikulum yang digunakan dalam pembelajaran.

Perangkat perencanaan selanjutnya adalah silabus. Silabus kurikulum IPC mempunyai konten yang rinci dalam mendesain pembelajaran yang efektif. Fulcher (2000, p.25) menjelaskan bahwa,"The syllabus sets the stage for the work that is to be completed, and clarifies expectations. As a "written contract" between two parties, the syllabus is a road map for the success of all parties concerned." Hal tersebut menegaskan bahwa silabus mendesain dan menetapkan tujuan dari serangkaian kegiatan yang harus diselesaikan sebagai "kontrak tertulis" dan peta jalan untuk keberhasilan semua pihak yang terkait. Silabus IPC sudah sesuai dalam memberikan gambaran rencana dan cara yang digunakan dalam mendesain pembelajaran efektif agar semua tujuan dalam pembelajaran dapat tercapai.
Dari silabus yang ada, perangkat pembelajaran selanjutnya adalah RPP berupa rencana yang menggambarkan prosedur dan menejemen pembelajaran untuk mencapai satu pembelajaran dasar yang ditetapkan dalam standar isi yang dijabarkan dalam silabus disusun oleh guru kelas masing-masing termasuk di middle grade. Guru di SD Tumbuh 3 Kota Yogyakarta menyusun RPP (di sana disebut dengan lesson plan). Lesson plan yang tersedia di SD Tumbuh 3 Kota Yogyakarta dirancang guru sebagai rencana dan gambaran pembelajaran yang disusun seminggu sekali. Lesson plan yang berupa plot agenda sederhana akan dibagikan kepada siswa di akhir pembelajaran dalam satu minggunya, biasanya di hari Jumat. Lesson plan yang dibagikan bertujuan untuk membangun komunikasi dengan orangtua tetang apa yang akan dilaksanakan dalam satu minggu ke depan. Lesson plan yang dibuat sudah sesuai dengan apa yang ada dalam panduan kurikulum dan silabus IPC yang digunakan dalam pembelajaran IPS. Lesson plan di SD Tumbuh 3 Kota Yogyakarta memang berbeda dengan RPP pada umumnya, hal ini juga dikarenakan penggunaan kurikulum dan silabus IPC memiliki komponen sendiri untuk ditampilkan dalam lesson plan.

Cruickshanks (2009, p.13) menyatakan bahwa "Lesson plan describe specifically what and how something will be learned within a brief periode, usually one or a few class hours". Rencana pelajaran menjelaskan secara spesifik apa dan bagaimana sesuatu akan dipelajari dalam periode singkat, biasanya satu atau beberapa jam pelajaran. Lesson plan yang ada di sekolah menjelaskan secara spesifik tentang apa saja kegiatan yang akan dilaksanakan oleh peserta didik setiap hari dalam satu minggunya. Semua kebutuhan yang berkaitan dengan pembelajaran juga tercantum jelas dalam lesson plan. Lesson plan yang ada di sekolah ini menjadi sarana komunikasi bagi sekolah dan orangtua di rumah agar senantiasa terlibat dan turut mengambil bagian terhadap kegiatan peserta didik di sekolah nantinya.

Perangkat perencanaan dilengkapi dengan mind map. Rangkaian kegiatan yang tertulis dalam lesson plan tiap minggunya ditampilkan secara menarik di dalam mid map. Mind map merupakan gambaran secara umum aktivitas dalam tema yang akan diajarkan selama tiga bulan. Mind map befungsi untuk menggambarkan aktivitas dalam lesson plan secara lebih umum dan ringkas. Selanjutnya jadwal akademik pembelajaran dalam satu semester ditam- 
Jurnal Prima Edukasia, 4 (1), Januari 2016 - 26

Anastasia Endah Anastika Dewi, Mukminan

pilkan secara jelas dan sistematis. Jadwal akademik di SD Tumbuh 3 Kota Yogyakarta dinamakan dengan timeline.

Perangkat perencanaan pembelajaran mulai dari kurikulum, silabus, lesson plan, mind map, dan timeline, semuanya disusun sesuai dengan kurikulum yang digunakan yaitu IPC. Semua perangkat perencanaan pembelajaran mampu memfasilitasi peserta didik dalam belajar secara aktif melalui pendekatan saintifik. Karakteristik dalam pendekatan saintifik dapat terfasilitasi sesuai dengan rangkaian kegiatan dalam IPC.

Perangkat perencanaan pembelajaran yang dikembangkan sesuai dengan pembelajaran berbasis pendekatan saintifik menjadi modal utama bagi guru untuk melaksanakan pembelajaran secara maksimal. Pembelajaran selau diawali dengan doa dan salam dari guru. Hal ini bertujuan untuk menarik perhatian peserta didik dan pengkondisian kelas agar pembelajaran segera dapat dimulai. Selanjutnya mulai masuk ke dalam pembelajaran melalui pendekatan saintifiik. Tahapan dalam pendekatan saintifik dimulai dari pertama, kegiatan mengamati, yang biasanya digunakan sebagai apersepsi guru. Kemudian kedua, kegiatan menanya yang biasanya dilakukan oleh guru ataupun siswa selama pembelajaran berlangsung. Tahapan ketiga mencoba dalam pembelajaran IPS sesuai dengan IPC sering juga dilakukan di luar kelas, seperti minitrip, menanam cabai, mengidentifikasi tanah yang termasuk dalam materi tema saving the world. Tahapan keempat yaitu menalar, guru terkadang membantu siswa dengan mengarahkan kepada pembelajaran yang kontekstual dan sesuai dengan tingkat berpikir peserta didik. Tahapan kelima mengkomunikasikan, aktivitas pembelajaran pa-da tahapan ini dapat berupa review bersama dengan guru diakhir pembelajaran dan juga kegiatan khusus sesuai dengan IPC yaitu Student Lead Converence (SLC), kegiatan mengkomunikasikan apa saja yang telah dipelajari selama satu tema di depan orangtua masingmasing. Diakhir pembelajaran selalu diberikan pesan moral terkait dengan materi yang telah dipelajari agar dapat diterapkan hal baik dalam kehidupan sehari-hari peserta didik.

Berdasarkan gambaran secara umum proses pelaksanaan pendekatan saintifik pada pembelajaran IPS di middle grade dapat dipastikan sudah berjalan dengan cukup baik dan membudaya. Pelaksanaan pembelajaran dapat diikuti dengan lancar oleh peserta didik. Tahap- an dalam pendekatan saintifik dapat terulang dalam satu kali pembelajaran, seperti menanya, mengamati dan juga melakukan dua tahapan sekaligus dalam satu kegiatan yang dilakukan dalam pembelajaran. Hal tersebut biasanya terjadi jika pembelajaran masuk ke dalam tahapan mencoba dengan memperhatikan contoh dan instruksi dari guru. Peserta didik melalukan tahapan mencoba dan sekaligus mengamti apa yang dicontohkan oleh guru.

McPherson (2001, p.242) mengungkapkan bahwa "the scientific method is the implication that there is a single list of steps, or recipe, that generates reliable knowledge". Sesuai dengan pembelajaran yang berlangsung di SD Tumbuh 3 Kota Yogyakarta bahwa pembelajaran IPS melalui pendekatan saintifik menjadikan pembelajaran mengacu pada metode ilmiah yang terdiri atas langkah-langkah yang mampu menghasilkan pengetahuan yang dapat diandalkan. Langkah-langkah atau tahapan yang sudah berjalan cukup baik di SD Tumbuh 3 Kota Yogyakarta mulai dari menanya sampai dengan mengkomunikasikan dapat terlihat semakin jelas secara parsial.

Semua tahapan dalam pendekatan saintifik telah terekam dalam aktivitas pembelajaran IPS, dan dapat diulas mendalam pada setiap tahapannya seperti berikut ini. Tahapan pertama adalah mengamati. Aspek mengamati dalam pembelajaran IPS di middle grade SD Tumbuh 3 Kota Yogyakarta telah dilaksanakan dengan baik. Mengamati merupakan bagian yang sangat penting dalam menunjang apersepsi yang diberikan oleh guru saat akan masuk ke dalam pembelajaran. Proses mengamati dalam pembelajaran IPS memang lebih sering dilaksanakan pada awal pembelajaran, dan terkadang akan muncul kembali bersamaan dengan aspek lainnya. Hal ini juga didukung oleh hasil wawancara dengan wali kelas/guru kelas middle grade sebagai berikut.

"aspek mangamati tersebut biasanya saya gunakan sekaligus sebagai apersepsi akan masuk ke dalam pembelajaran. Memang tidak semua anak dapat melakukan aktivitas mengamati dengan jeli dan baik. Tapi justru itulah, kemungkinan perbedaan pendapat dari apa yang mereka amati sangat menarik bagi saya. Misalnya dengan satu objek saja akan menghasilkan banyak interpretasi yang beragam dari mereka, ini sangat menarik bagi kami."'(Wawancara 8. DD: Tanggal 14 Januari 2015). 
Jurnal Prima Edukasia, 4 (1), Januari 2016 - 27

Anastasia Endah Anastika Dewi, Mukminan

Hal tersebut juga sesuai dengan Kovalik \& Olsen (2010, p.73) yang menyatakan bahwa:

Observing is the scientific thingking process from which fundamental patterns of the world are constructed. the main route to knowledge is through observing, using all the senses, a process through which people come to know about the characteristics of objects and their interactions.

Kovalik \& Olsen berpendapat mengamati adalah proses berfikir ilmiah di mana pola dasar dunia mulai dibangun. Jalan utama dalam memperoleh pengetahuan adalah melalui mengamati, menggunakan semua indera, melalui proses di mana orang ingin mengetahui tentang karakteristik objek dan interaksi mereka. Sehingga tahapan mengamati yang ada di SD Tumbuh 3 Kota Yogyakarta telah sesuai di mana tahapan mengamati biasanya diguna-kan sebagai apersepsi pembelajaran sebagai jalan memperoleh pengetahuan menggunakan semua indera untuk mengetahui karakteristik objek ataupun materi yang diberikan oleh guru.

Tahapan selanjutnya adalah menanya. Dalam pembelajaran, peserta didik biasanya mengajukan pertanyaan atau menjawab pertanyaan yang diberikan oleh guru terkait dengan observasi sebelumnya. Peserta didik selalu mengangakat tangan terlebih dahulu dan menunggu untuk disebut namanya, kemudian bertanya ataupun menjawab pertanyaan. Aktivitas menanya dalam pembelajaran IPS dapat terjadi lebih dari satu kali. Guru selalu menggunakan aktivitas menanya untuk membantu siswa mengungkapakan pendapatnya serta untuk mengetahui sejauh mana pemahaman anak terhadap apa yang akan mereka tanyakan dan amati (obervasi). Guru dapat mengidentifikasi pertanyaan yang diajukan peserta didik, apakah mereka benar-benar sudah paham apa yang akan dipelajari atau belum. Hal ini juga dikuatkan oleh hasil wawancara dengan wali kelas/ guru kelas sebagai berikut. "Dari aktivitas menanya terkadang kami
yang memberikan beberapa pertanyaan, dan
mereka akan menjawab, bahkan walaupun
tidak mengetahui jawabannya anak-anak
tetap akan mengangkat tangan dan berebut
untuk menjawab. Hal itu sangat menarik.
Mereka juga mengajukan pertanyaan,
menginginkan sebuah penjelasan lebih dari
apa yang sudah mereka ketahui. Hal ini
menjadi bagian yang sangat penting dan menarik bagi saya, semuanya akan membantu saya mengidentifikasi apakah anak paham akan apa yang mereka tanyakan, dan paham akan pelajaran yang diterimanya."(Wawancara 9. DD: Tanggal 14 Januari 2015).

Tahapan mencoba atau eksperimen akan lebih baik jika dilakukan dalam semua pembelajaran IPS. Hal ini juga didukung dengan hasil wawancara bersama wali/guru middle grade SD Tumbuh 3 Kota Yogyakarta sebagai berikut.

"Awalnya mendengar eksperimen menjadi bagian dari pendekatan saintifik dalam pembelajaran IPS sepertinya sangat jarang ditemukan. Tapi perkembangan pembelajaran yang sangat luar biasa, menjadikan tantangan tersendiri bagi saya dan tim guru kelas ini, mengemas eksperimen dalam IPS menjadi menarik dan tanpa terkesan memaksakan. Saya selalu mengusahakan walaupun eksperimen itu kecil, percobaan itu sederhana harapan saya dari aktivitas tersebut anak-anak menjadi pembelajar sejati. Mereka melakukan, tidak hanya menerima. Itu yang terpenting menurut kami disini." (Wawancara 10. DD: Tanggal 20 Januari 2015.

Tahapan mencoba di SD Tumbuh 3 Kota Yogyakarta diarahkan agar peserta didik mengalami proses secara langsung, yang terpenting adalah peserta didik dapat "melakukan" bukan hanya "menerima" saja. Lorreta (2011, p.19) mengungakapankan bahwa aktivitas mencoba atau melakukan penyelidikan di sekolah dasar dapat dilakukan melalui penyelesaian proyekproyek kelompok, kegiatan diskusi, untuk mengembangkan rasa bagaimana belajar penyelidikan secara langsung. Pada saat yang sama, mereka mampu belajar konten yang diperlukan dengan bimbingan guru.

Gambaran aktivitas mencoba dalam pembelajaran di sekolah dasar sangat memungkinkan dilakukan dalam pembelajaran IPS, hal ini sudah dilakukan di SD Tumbuh 3 Kota Yogyakarta dan dapat berjalan dengan baik tanpa menemukan kendala yang berarti. Peserta didik juga sudah sangat terbiasa dan percaya diri dengan pembelajaran yang banyak melibatkan aktivitas mandiri baik dalam kelompok maupun tugas secara individu.

Tahapan selanjutnya dalam pendekatan saintifik adalah menalar. Tahapan ini juga 
Jurnal Prima Edukasia, 4 (1), Januari 2016 - 28

Anastasia Endah Anastika Dewi, Mukminan

muncul dalam pembelajaran IPS di SD Tumbuh 3 Kota Yogyakarta. Bahkan terkadang peserta didik langsung dapat dengan begitu baik menalar dari rangkaian informasi dan pengalaman yang telah mereka dapatkan. Peserta didik cukup kooperatif jika diarahkan untuk dapat menghubungkan segala informasi yang telah didapatkan. Hal ini juga didukung dengan hasil wawancara bersama wali kelas/guru kelas sebagai berikut.

\begin{abstract}
"Kemampuan anak menalar harus dibiasakan dengan mempertimbangkan seтиa informasi yang didapatkan dan tidak sembarangan dalam nantinya menarik sebuah konsep atau kesimpulan. Apalagi kita tentunya sangat memahami bagaimana IPS ini sangatlah dinamis. Anak-anak sudah terlibat secara tidak langsung di rumah melalui media, nahh.. itu dapat kita manfaatkan dalam membimbing anak untuk dapat mengikuti perkembangan pengetahuan di luar sana dengan apa yang diterimanya di sekolah, sesuai dengan tujuan pembelajaran yang telah dirancang."(Wawancara 12. DD. 15 Januari 2015).
\end{abstract}

Chaterine (2007, p.13) mengungkapkan bahwa dalam aktivitas berpikir secara ilmiah peserta didik harus diarahkan untuk dapat berpikir kritis termasuk di dalammnya adalah melakukan penalaran konseptual sesuai dengan rangkaian fakta yang telah didapatkan melalui tahapan sebelumnya. Penelaran merupakan ciri dan bagian dalam berpikir secara kritis. Peserta didik di SD Tumbuh 3 Kota Yogyakarta dapat dengan mudah diarahkan untuk menalar melalui beberapa contoh yang diberikan oleh gurunya serta menghubungkan dari beberapa fakta yang telah mereka dapatkan dari serangkaian aktivitas sebelumnya dalam pendekatan saintifik. Kedinamisan IPS sangat mendorong peserta didik untuk dapat mengasosiasikan segala informasi yang telah didapatkan dengan pengetahuan-pengetahuan baru yang nantinya muncul dalam kegaiatan pembelajaran selanjutnya.

Mengkomunikasikan merupakan tahapan terakhir dalam pendekatan saintifik, aktivitas yang terekam berdasarkan pengamatan yang dilakukan adalah guru selalu berusaha mengarahkan peserta didik agar mampu mengkomunikasikan apa yang telah mereka dapatkan tentang suatu konsep dari fakta-fakta yang ada dan telah diasosiasikan (menalarnya). Salah satu kegiatan mengkomunikasikan dalam tahapan ini adalah $S L C$ dan review, semua dilakukan secara baik oleh peserta didik dengan bimbingan guru. Aktivitas mengkomunikasikan mulai dari yang sederhana berupa review bersama dengan guru dan yang membutuhkan persiapan khusus melalui kegiatan SLC mengkomunikasikn semua yang telah dipelajari di depan orangtua.

Secara keseluruhan tahapan pendekatan saintifik dalam pembelajaran IPS di SD Tumbuh 3 Kota Yogyakarta sudah berjalan dengan baik. Tahapan mulai dari mengamati, menanya, mencoba, menalar dan mengkomunikasikan berjalan secara berurutan sesuai dengan materi pembelajarannya. Dilain kesempatan beberapa tahapan itu dapat muncul kembali dan diulang terkait dengan aktivitas pembelajaran yang diberikan oleh guru. Joyce (2009, p.7) mengungkapkan bahwa dalam pembelajaran IPS dengan menggunakan pendekatan ilmiah melalui beberapa tahapan sebagai berikut, "created a recursive process of theory, observation, analysis, coteaching, and reflection". Pernyataan tersebut dapat dimaknai bahwa dalam tahapannya perlu adanya pengulangan teori, observasi, analisis atau proses menalar dan pendampingan oleh guru sampai kepada refleksi untuk mengkomunikasikan apa yang telah diperoleh.

Pengulangan yang terjadi dalam pembelajaran dengan pendekatan saintifik dapat saja terjadi dan hal tersebut tidak menjadi masalah, kerena pengulangan tersebut dibutuhkan dalam membangun pengetahuan yang kuat sebagai modal dalam melaksanakan tahapan selanjutnya.

setelah mengetahui pelaksanaan pembelajaran melalui pendekatan saintifik, maka penilaian otentik tidak dapat dilepaskan dalam rangkaian pembelajaran tersebut. Penilaian yang ada di middle grade memang belum sepenuhnya sesuai dengan penilaian otentik untuk menilai berbagai pembelajaran peserta didik, atau kombinasi dari pengetahuan, keterampilan, sikap, yang dapat mereka aplikasikan dalam kriteria situasi dalam kehidupan yang professional. Pelaksanaan penilaian otentik di middle grade mengalami beberapa ketidaksesuain, penilaian belum mencakup semua aspek baik kognitif, afektif dan psikomotorik secara lengkap dan sistematis. Adanya beberapa pembelajaran yang tidak memperoleh perlakuan sama, seperti yang terjadi di mid semeter, hal ini tentunya menimbulkan ketidaksesuaian dengan maksud penilaian otentik yang menyeluruh. Penilaian otentik terkait dengan implementasi pendekatan saintifik dalam pembelajaran IPS belum berja- 
Jurnal Prima Edukasia, 4 (1), Januari 2016 - 29

Anastasia Endah Anastika Dewi, Mukminan

lan baik dan sesuai. Hal ini juga dipertegas dengan pernyataan wali kelas/guru kelas dalam hasil wawancara sebagai berikut.

"Sebenarnya masalah penilaian di sekolah ini, tidak hanya di middle grade, apalagi terkhusus hanya dalam IPS yang masuk ke dalam IPC, penilaian otentik disini memang belum sesuai. Dengan pendekatan yang kami gunakan dengan scientific approach memang sebenarnya akan lebih baik dan sesuai jika penilaian yang sistematis mencakup kognitif, afektif, dan psikomotorik. Namun pada mid kita menggunakan nilai 110, bukan skor yang seperti digunakan dalam raport 1-4. Kemudian IPC tidak ikut untuk di mid semester. Nahh ini semua sebenarnya juga merupakan tanda tanya besar bagi kami, dan bahkan bagi wali murid. Tapi sebagai evaluasi kedepannya semuanya harus segera disesuaikan." (Wawancara 15. DD: Tanggal 24 Januari 2015).

Penilaian otentik merupakan penilaian yang tidak dapat dipisahkan jika pembelajaran dilaksanakan dengan pendekatan saintifik. Dengan penilaian otentik maka penilaian telah dilakukan secara menyeluruh mencakup semua aspek baik kognitif, afektif, dan psikomotorik yang dapat muncul dalam serangkaian tahapan pembelajaran dengan pendekatan saintifik. Todorov (1998, p.1) mengungkakan sebagai berikut.

"The authentic assesment has as it goal the developmental of volountary classroom level assesment to asses student progress towards meeting the important standardt of conducting investigation, group discussion and responsible personal conduct.

Hal tersebut menjelaskan bahwa penilaian otentik mempunyai tujuan untuk menilai perkembangan peserta didik sesuai dengan tingkatan kelas dengan sebuah standar yang meliputi pengamatan tingkah laku peserta didik dalam investigasi, kelompok diskusi dan respon. Semua aspek haruslah dinilai sesuai dengan aktivitas pembelajaran yang dilakukan oleh peserta didik. penilaian yang ada di SD Tumbuh masih kurang sesuai dengan prisip dari enilaian otentik yang menyeluruh meliputi semua aspek dan dilakukan secara berkesinambungan.

Dari proses penilaian diharapakan guru mendapatkan hasil belajar yang dapat diguna- kan dalam mengidentifikasi tercapainya kompetensi yang diinginkan dalam suatu pembelajaran. tidak semua peserta didik dapat dengan mudah mencapai suatu kompetensi yang telah ditetapkan ada yang mampu mencapai dan tuntas ada juga yang belum mampu mencapai sehingga membutuhkan bimbingan dan tindak lanjut dari guru terkait dengan pembelajaran tersebut. Tindak lanjut di SD Tumbuh 3 Kota Yogyakarta diberikan kepada peserta didik yang belum mampu mencapai kompetensi dan yang telah mampu mencapai kompetensi. Tindak lanjut yang dilaksanakan di middle grade SD Tumbuh 3 Kota Yogyakarta berupa program morning carpet. Morning carpet merupakan rangkaian kegiatan yang dilakukan di pagi hari sebelum masuk ke dalam pembelajaran. Kegiatan yang ada dalam morning carpet dikemas dalam game atau permainan. Kegiatan morning carpet diikuti oleh semua siswa, hal ini bertujuan sebagai pengulangan pembelajaran, dan pemantapan kembali bagi peserta didik yang belum mencapai pembelajaran.

Tambahan waktu untuk bimbingan diberikan kepada kedua peserta didik di middle grade yang belum bisa membaca dan menulis dengan lancar, sehingga sering tertinggal dengan teman lainnya dalam mencapai pembelajaran. Selain memberikan bimbingan membaca, guru juga memberikan beberapa ulasan kembali materi pembelajaran. Tambahan waktu yang diberikan diharapkan dapat meningkatkan kemampuan membaca dan menulis, sehingga pembelajaran dapat diikuti dengan lancar.

Tindak lanjut di middle grade SD Tumbuh 3 Kota Yogyakarta dikoordinasikan dengan orang tua atau wali peserta didik. Hal ini diharapkan dapat terjalin kerja sama yang berkesinambungan dalam membimbing peserta didik di rumah, agar kendala yang dihadapi peserta didik dapat segera diselesaikan.

Tindak lanjut dilaksanakan bukan hanya semata-mata bagi peserta didik yang belum mencapai ketuntasan namun juga untuk peserta didik yang telah mencapai kompetensi dalam pembelajaran agar kemampuan berpikir kritis yang menjadi ciri dalam pendekatan saintifik dapat diasah dan membantu peserta didik dalam memahami konsep pembelajaran yang telah didapatkan.Serangkaian tahapan pendekatan saintifik di SD Tumbuh 3 Kota Yogyakarta dapat berjalan dengan baik dalam pembelajaran IPS di middle grade. Kondisi middle grade yang terdiri atas peserta didik usia 8-10 tahun, di mana tahapan berpikir mereka konkret, inte- 
Jurnal Prima Edukasia, 4 (1), Januari 2016 - 30

Anastasia Endah Anastika Dewi, Mukminan

gratif dan hirarkis. Dengan menggunakan pendekatan saintifik dalam pembelajaran IPS melalui tema yang terintegrasi pembelajaran dapat disajikan secara lebih konkret melalui tahapan ilmiah yang ada, sehingga peserta didik lebih banyak terlibat secara langsung. Selain itu pada usia middle grade peserta didik sudah lebih mampu untuk berpikir hirarkis, berpikir dimulai dari hal yang sederhana ke hal yang lebih kompleks. Demikian juga tahapan dalam pendekatan saintifik, sehingga anak usia middle grade di SD Tumbuh 3 Kota Yogyakarta sangat sesuai jika dalam pembelajarannya, khususnya pembelajaran IPS dilaksanakan dengan pendekatan saintifik.

Daniels (2010, p.15) mengungkapkan pandangan ilmiah terkait dengan usia anak sekolah dasar dalam pembelajaran dengan scientific approach sebagai berikut "... from the scientific view, children do think, feel, and behave quite differently at age 7 or 8 than they did when they were 4 or 5." Artinya usia di mana anak mulai mampu untuk berpikir, merasakan, dan berperilaku dengan cukup berbeda ketika berusia 7 atau 8 tahun daripada yang mereka lakukan ketika mereka masih di usia 4 atau 5 tahun. Dengan kondisi tersebut, maka peserta didik di usia 7 atau 8 tahun akan cukup kooperatif untuk diarahkan pada pembelajaran yang melibatkan aktivitas berpikir, merasa, dan juga bersikap lebih ilmiah.

Tahapan di dalam pendekatan saintifik memfasilitasi peserta didik untuk dapat berpikir secara hirarkis, dimulai dari aktivitas mengamati dan menanya, secara sederhana mereka berpikir berdasarkan apa yang terlihat. Melakukan eksperimen dan menalar dari fakta yang ditemukan mendorong peserta didik untuk mulai berpikir lebih kompleks. Selanjutnya mereka diharapkan dapat mengkomunikasikan dengan baik tentang konsep yang telah didapatkan.

Hal tersebut juga didukung dengan kondisi dan tingkat perkembangan berpikir peserta didik pada usia 8-11 tahun di mana cara belajar mereka adalah konkret dengan melihat secara langsung dan mengalaminya secara langsung. Terintegrasi dalam tema yang telah disusun sesuai dengan kompetensi yang akan dicapai peserta didik serta hirarkis belajar belajar mulai dari hal paling konkret menuju kepada hal abstrak berupa konsep-konsep yang semuanya mereka temukan dalam meteri pembelajaran IPS.

Implementasi pembelajaran IPS mulai dari perencanaan sampai kepada tindak lanjut dalam pelaksanaanya ditemukan beberapa faktor yang menjadi kendala atau penghambat. Faktor-faktor yang menghambat kelancaran proses implementasi pendekatan saintifik pada pembelajaran IPS di middle grade SD Tumbuh 3 Kota Yogyakarta diantaranya adalah (a) sistem penerimaan siswa yang kurang transparan tanpa melibatkan guru sebagai ujung tombak pelaksanaan pembelajaran di kelas, (b) ada beberapa anak yang masih kesulitan dalam membaca dan menulis, (c) penilaian kurang sesuai, (d) jumlah jam pembelajaran IPS trerbatas dan guru tidak membatasi bobot cakupan materi IPS sesuai dengan tingkat perkembangan berpikir peserta didik.

Selain ditemukannya faktor penghambat ditemukan sedikitnya ada empat faktor pendukung yang terlihat begitu menonjol dalam proses penyelenggaraan pendidikan di SD Tumbuh 3 Kota Yogyakarta. Keempat faktor tersebut adalah (a) kepala sekolah yang tangguh, selalu terlibat dalam segala aktivitas baik memantau jalannya pembelajaran dan aktivitas bermain bersama dengan peserta didik, (b) guru-guru yang semangat dan profesional, menjalankan tugas sepenuhnya sebagai pendidik dengan kedekatan yang dibangun agar tercipta kenyamanan dalam belajar, (c) iklim sekolah yang kondisif, menjadikan suasana belajar semakin semangat, (d) sarana prasarana yang lengkap.

Keempat faktor pendukung tersebut dapat menjadi kekuatan dalam menyelesaikan masalah terkait pembelajaran mulai dari hal penerimaan siswa sampai kepada penilaian serta kondisi beberapa siswa yang belum lancar dalam membaca dan menulis. Semuanya dapat diatasi dengan baik sesuai dengan apa yang menjadi tujuan dari SD Tumbuh 3 Kota Yogyakarta untuk menjadikan peserta didik sebagai warga dunia yang aktif dan dapat menyelesaikan masalah melalui pembudayaan pembelajaran dengan pendekatan saintifik.

\section{Simpulan dan Saran}

Bertolak dari uraian pembahasan, secara sederhana dapat ditarik benang merah sebagai berikut. (1) Proses implementasi pendekatan saintifik pada pembelajaran IPS di middle grade SD Tumbuh 3 Kota Yogyakarta telah berjalan dengan cukup baik karena pelaksanaan pendekatan saintifik sudah membudaya dan tidak mengalami kendala cukup berarti. Proses pembelajaran berorientasi pada proses atau recording activity. (2) Perencanaan pembelajar- 
Jurnal Prima Edukasia, 4 (1), Januari 2016 - 31

Anastasia Endah Anastika Dewi, Mukminan

an dengan pendekatan saintifik pada pembelajaran IPS disusun sesuai dengan kurikulum yang memuat pembelajaran IPS yaitu Intenational Primary Curriculum (IPC). (3) Pelaksanaan pendekatan saintifik telah berjalan dengan baik dan membudaya. (4) Penilaian pembelajaran IPS yang diajarkan dengan pendekatan saintifik belum tersedia khusnya penilaian otentik terkait pembelajaran IPS. (4) Tindak lanjut dalam pembelajaran IPS dengan pendekatan saintifik sudah diberikan sesuai dengan kebutuhan. (5) Kesesuaian antara pendekatan saintifik dengan karakteristik anak middle grade telah terbukti melalui pembelajaran IPS yang menyenangkan.

Berdasarkan simpulan penelitian maka dapat dikemukakan saran seperti berikut: (1) kepala sekolah hendaknya memperbaiki sistem penerimaan siswa agar lebih bersifat transparan dan melibatkan guru sebagai ujung tombak yang akan berhubungan secara langsung dalam proses pembelajaran. Perumusan kriteria untuk anak berkebutuhan khusus dan prosentase dalam satu kelas perlu dikaji dan diperhatikan, demi keberlangsungan proses pembelajaran yang lebih baik melalui pendekatan saintifik. (2) Guru harus tetap profesioanl meskipun ada sejumlah kendala yang menghadang baik dari segi peserta didik dan sistem penilaian, tetap mengembangkan pembelajaran IPS dengan pendekatan saintifik. Penilaian yang belum sesuai harus segera dilengkapi sebagai bentuk pertanggungjawaban atas apa yang telah dicapai peserta didik secara keseluruhan (kognitif, afektif, dan psikomotorik). (3) Yayasan Anak Nusantara akan lebih baik jika SD Tumbuh 3 Kota Yogyakarta fokus menggunakan satu kurikulum sebagai acuan dalam proses pembelajaran dengan tetap menggunakan pendekatan saintifik. Dengan demikian peserta didik akan semakin memiliki ruang dan fokus pembelajaran yang jelas. Selain itu, diharapkan konsep fun learning akan tetap terlaksana dengan baik di SD Tumbuh 3 Kota Yogyakarta.

\section{Daftar Pustaka}

Catherine, L.A. (2007). A study curriculum effectivenes in social studies. Journal of Education and Rehabilitation Psychologi.Volume 51, Februari 2007.

Cruickshank, D.R. (2009). The Act of Teaching. New York. Graw-Hill.
Daniels, Clarkson. (2010). A developmental approach to educating young children. California: A SAGE Company.

Depdiknas. (2003). Undang-Undang RI Nomor 20, Tahun 2003, tentang Sistem Pendidikan Nasional. Pasal I.

Eidities, L., \& Jewkes, A. M. (2011). Making curriculum decision in $\mathrm{k}-8$ science: the relationship between teacher dispositions and curriculum content. Journal of Geoscience Education , 59, 4, 242-250.

Fulcher KY, white PD, (2000). Strenght and physiological response to exercise in patients with crhonic fatigue syndrome: Journal of neurology, neurosurgery and psychiatry,69:302-307.

Joyce, B.H. (2009). Do as i say and do as i do: using the professor-in residence in teaching social studies methods. Journal of Sociology, Social Sciences, Comprehensive Works Education. Vol. 100. Page 7.

Kovalik, J.S \& Olsen, D.K. (2010). Kid's eye view of science: a conceptual integrated approach to teaching science. California. A SAGE Company.

Loretta, J.L., et.al. (2011). Using technology to enggage preservice elementary teachers in learning about scientific inquiry. Center of Educational Policy Studies Journal. Volume 1.Page 19.

McPherson, G.R. (2001). Teaching and learning the scientific method. The American Biology Teacher. Vol 63.4.page 242

Milles, M.B, \& Huberman, A.M. (1992). An Expanded Sourcebook Qualitative Data Analysis.(zed ed). London: SAGE Publication.

Holbrook, Jack. (2008), An education through science approach to promoting 21 st Century Skills. Swiss: University of Tartu \& ICASE

Todorov. (1998). Authentic assessment of social studies. Canada: Michigan Departement of Education.

Williams, J.D. (2011). How Sscience works teaching and learning in the science classroom. London: SAGE Publication, Inc. 